\title{
Assessing Safety of Ferry Routes by Ship Handling Model through AHP and Fuzzy Approach
}

\author{
Antoni Arif Priadi ${ }^{1}$, Tri Tjahjono ${ }^{2}$, Abdellatif Benabdelhafid ${ }^{1}$ \\ ${ }^{1}$ Laboratoire de Mathématiques Appliquées, University of Le Havre, Le Havre, France \\ ${ }^{2}$ Departement of Civil Engineering, University of Indonesia, Jakarta, Indonesia \\ Email: antoni-arif.priadi@etu.univ-lehavre.fr, tri.tjahjono@ui.ac.id, abdellatif.benabdelhafid@univ-lehavre.fr
}

Received August 30, 2012; revised October 2, 2012; accepted October 13, 2012

\begin{abstract}
Ferry accidents often occur the result of ship handling difficulty which interfacing human, machine and environment. Therefore, a decision tool model as a comprehensive information system, based on the ship handling difficulty, needs to be developed through the combination of Analytic Hierarchy Process (AHP) and Fuzzy Logic System. The Fuzzy Logic System part consists of ship condition, ship handling facility condition, navigation condition and weather condition. The output of decision tool is the ship handling difficulty level in linguistic form. The simulation of model is conducted at several straits in Indonesia water. The decision tool model could be used as management information system by port authority to monitor the ferry/ship movement in real time regarding the ship handling difficulty. Further, it would be used to take some useful safety operation strategies and safety policies to improve ferry transportation safety at port water and strait water.
\end{abstract}

Keywords: Ro-Ro Ferry; AHP; Fuzzy; Ship Handling

\section{Introduction}

The maritime transportation affects most of goods and passengers movement among islands in an archipelago country, Indonesia. As the result, the reliability of maritime transportation to link among islands will impact to the development of country especially in the frame of economic sector. The maritime transportation could be divided into two categories which are sea transportation and crossing transportation. The crossing transportation bridges among places as the continuation of road or railway by crossing the straits. The most type of transportation means for this category use Ro-Ro ferries. A Ro-Ro ferry is a type of ship where generally able to carry both passengers and vehicles on same time. The vehicles could be private cars or commercial vehicles such as truck, bus, lorry etc.

Ferry routes are divided by three categories such as, commercial route, pioneer route subsidized by government and pioneer route non-subsidized by government. The numbers of routes in operation have increased from 99 routes in 2006 and 155 routes in 2010 [1]. The detail number of route is presented in Figure 1.

Figure 2 shows the type of crossing transportation means condition during 2006 and 2010 in Indonesia [1]. It clarifies that Ro-Ro ferries during 2006-2010 have played very principal roles for serving ferry transporta- tion means. Meanwhile, it also showed that the number of Ro-Ro ferry has risen in number.

Nevertheless, the significance role of Ro-Ro ferry is not free from the consequences of ship handling. In Figure 3, it is shown that there were 24 ferries/Ro-Ro accidents during 2003 and 2009 which compose of 25\% of sinking, $25 \%$ of fire and $29 \%$ of grounding [2].

The cause of the ship accident at Indonesia during 2007-2009 may be categorized by several causal factors such as weather factor constitute of $34 \%$ followed by $27 \%$ of human factor and followed by $18 \%$ of technical factor [2].

The ship operation system contains of complex interrelation among technical factor, environment factor as well as human factor that control the ship handling process. One idea of the event of ship accident is the idea of ship handling process. The ship handling is defined as the practice of guiding a ship which controls ship movement through ship controllability means, visual monitoring means and instrumental monitoring. Therefore, ship navigation operation and ship maneuvering are the integrated part of the ship handling. The successful of ship handling will bring accident far away from it might be happened. In other word, if there is a problem with ship handling process such as the difficulty of controlling ship behavior, it might lead to accident. It could be generalized that ship handling difficulty potentially directs to 


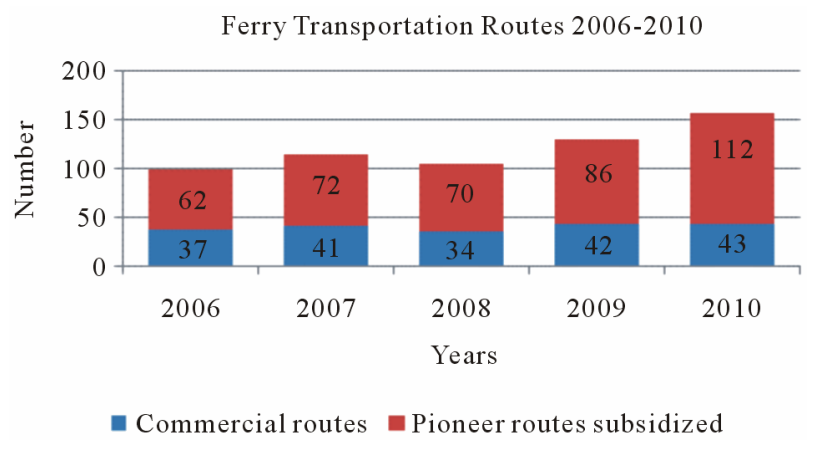

Figure 1. The numbers of Ro-Ro ferry routes in Indonesia (2006-2010).

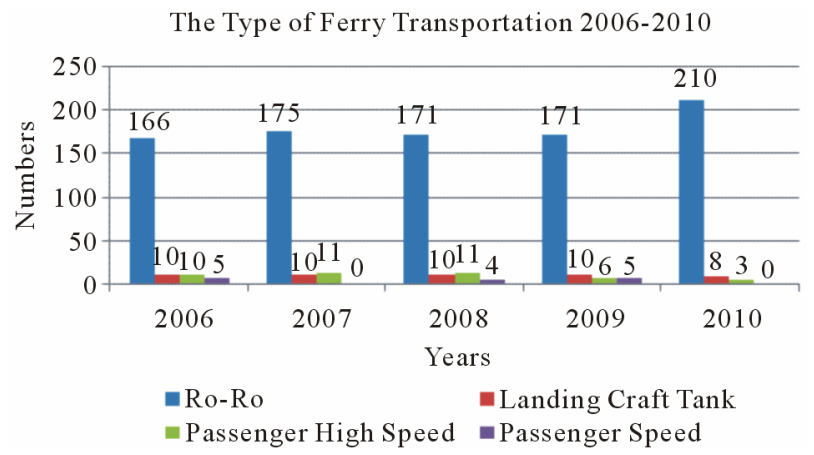

Figure 2. Number of means for transporting cargo and passenger across islands in Indonesia (2006-2010).

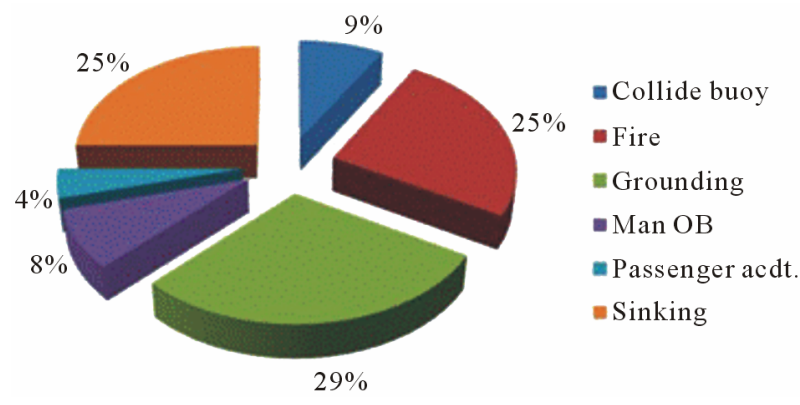

Figure 3. Percentage of Ro-Ro accident in Indonesia (20032009).

ship accident [3].

The ship handling difficulty will transmit a signal to ship officer in charge to take action properly to current ship handling situation which it depends among technical issues, environment issues and human issues. Here, the information system bridge among human factors, technical factors, environment factors. The use of appropriate information will guide the officer to take an appropriate action and vice versa. Therefore, in the writer's opinion, the information system through decision support system in the complex criteria situation as consequences of ship handling difficulty is one challenge answer to minimize the potential of ship accident. The development of ship handling model for ferry at port water and strait water based on Analytic Hierarchy Process and Fuzzy Inference System approach has been developed [4]. The model is named AHP FIS which consisted of four criteria such as ship condition with six factors, ship handling facility condition with six factors, navigation condition with six factors and weather condition with six factors. The total numbers of factors considered are 24 factors. The output of model is ship handling values which determine the level of ship handling difficulty.

The aim of this paper is to assess the ship handling level of ferry at several straits in Indonesia such as Bali Strait and Lombok Strait through the paper order of introduction, the overview of AHP FIS ship handling model, simulation result and conclusion.

\section{The Overview of AHP FIS Ship Handling Model}

The AHP FIS ship handling model is based on two methods. The first method is Analytical Hierarchy Process (AHP) which is used for analyzing multi criteria decision problems with multiple criteria. The method of analytic hierarchy process (AHP) has been used for this purpose [5]. The hierarchy structure of complex estimation criteria can be represented clearly and definitely. Then, ratio scale can be utilized to make reciprocal comparison for each element and layer. When the reciprocal matrix is developed, weight comparison for each element can be obtained. A paper has proposed the AHP for weighing factor of ship danger score during sailing at sea [6]. Additionally, the method is also used for choosing the container port in multiple port regions [7] as well as for assessing ship system risk [8].

The second method is Fuzzy Inference System (FIS). The FIS consists of fuzzifier, fuzzy inference system and defuzzifier. Generally, it is a method of calculation using linguistic/word variables, as a replacement of counting numbers [9]. Meanwhile, the linguistic/words used in fuzzy logic are not as accurate numbers, nevertheless the words used are closer to human intuition. A paper was proposed using a fuzzy logic method for determining the probability of occurrence (event probability) and conesquence of occurrence on formal safety assessment on LNG carrier [10]. It was begun with the uncertainty of system failure on the LNG carrier vessel. Uncertainty LNG carrier system failure in limited water was assumed at subjectivity of navigational safety, subjectivity of maneuverability, and subjectivity of collision avoidance. The end output of the research is the risk index of common hazards which previously calculated in event probability.

The research on high speed craft ship on the navigation system had been performed [11]. The research was begun with the difficulty to assess and analyze the quan- 
tity of high speed craft navigation safety factor so formal safety assessment method based on fuzzy analytic hierarchy process was done. The development of the system of risk assessment factors for high speed craft navigation depends upon three different things which are operator, the movement of high speed craft and environment. In such research include the assessment of safety factor of four parts, namely landform of the navigation channel, hydrometeorology, traffic, and navigation mark.

The research on new approach in maritime risk assessment for safety at sea which was based on risk factor as a new development tool of decision that were equipped on VTIS or naval communication and information system (CIS) so the individual risk of particular ship could be monitored was conducted through fuzzy expert system [12]. An expert system is a tool that mimics the cognitive mechanisms of human expertise. This system consists of three parts, namely an event base, rule-based and inference engine. In their research, they have used static risk factors and dynamic risk factors to determine the final result of individual ship risk factor.

In reference [13], the use of fuzzy method as a tool for safety assessment had been performed. It is associated with classical safety assessment (PRA: probabilistic risk assessment) which has its disadvantages, especially re- lated to systems that have fairly high degree of uncertainty such as design of feasibility and design of system. A significant contribution of theory of fuzzy systems is the availability of systematic procedure to change the knowledge based into a non linear mapping. Fuzzy IF THEN rules is a statement IF THEN in which some words are characterized by continuous membership function. For example: IF the likelihood of hazard is frequent AND severity of occurrence is catastrophic, THEN the risk level is high. In this case, frequent, catastrophic and high are membership functions. The fuzzy system is constructed from the collection of fuzzy IF THEN rules. In summary, the fuzzy logic method has been used in several researches to deal with uncertainty condition, the lack of official data, the simplicity of method to handle complex system, the possibility of involvement of expert knowledge system. The fuzzy logic system as mentioned above has been used as a decision tool to monitor individual ship risk with several parameters.

The detail of AHP FIS ship handling model architecture is illustrated in Figure 4. The first step of proposed model is the output of AHP model which are consist of four variables such as ship condition, ship handling facility condition, navigation condition and weather condition. Such outputs then are utilized as input of second step

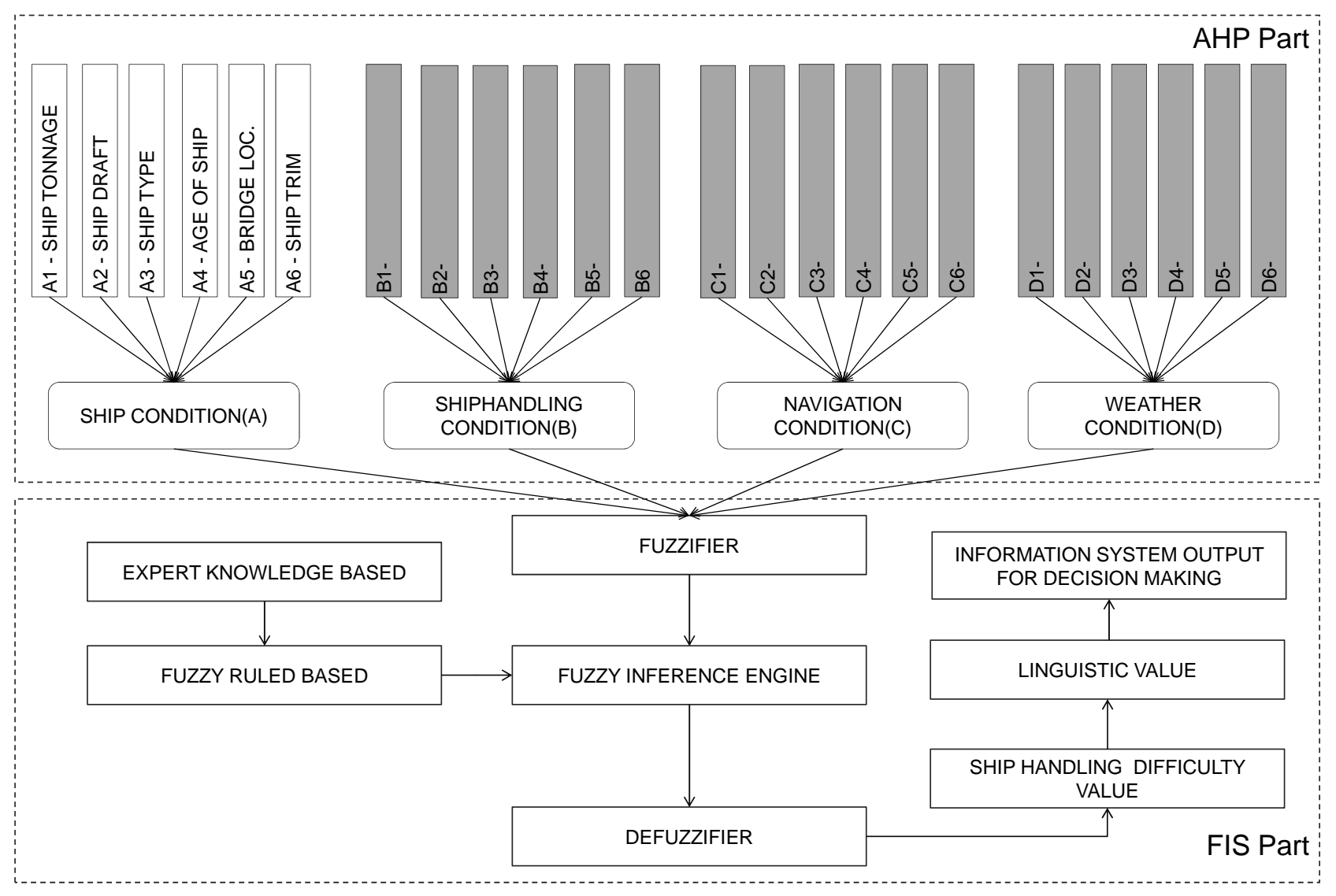

Figure 4. AHP FIS ship handling model structure. 
which is fuzzy logic step. The method of Mamdani (Max-Min) is used on this model. The method Mamdami is used because of several advantages such as intuitive, wide accepted and suitable by human input. The procedure of fuzzy inference system (FIS) is begun with the development of membership function $(\mu)$, the development application of implication function, the development of rule composition and defuzzification. The detail process is illustrated in Figure 4.

The construction of AHP part is based on previous research [14]. Meanwhile the FIS part construction is based on previous research [4]. Similar approach was performed to determine the rank of ship which will be inspected [12]. This approach has used dynamic risk factors and static risk factors for fuzzy risk evaluation. The static risk evaluation factors consist of ship flag, year of construction, gross tonnage, number of companies, duration of detentions and type of ship. Meanwhile, dynamic risk evaluation factors consist of sea state, wind speed, visibility, and night or day. They used such factor without any justification for determining which factor has importance priority among others. The AHP FIS model uses AHP approach to determine the importance level of factors which are then processed through fuzzy logic. This approach could give a way to limit level of uncertainty before input factors are processed through fuzzy inference system. It also will simplify the development of rules in fuzzy inference system.

\section{The AHP FIS Algorithm}

In this section, the overall of algorithms which are used to construct the AHP FIS ship handling model is presented. The algorithm is presented from the development of fuzzy membership function until the end of result which is ship handling difficulty.

$$
\mu S(t)=\left(\mu S(t), S H D_{a}(t)\right)
$$

where $S H D_{a}(t)$ is obtained from

$$
\operatorname{SHD}_{a}(t)=s^{t h} \sum_{n=1}^{N} A_{n} P_{a n}
$$

and $A_{n}$ is function of $A_{1}, A_{2}, A_{3}, A_{4}, \cdots, A_{6}$

$$
A_{n}=f\left(A_{1}, A_{2}, A_{3}, A_{4}, \cdots, A_{6}\right)
$$

where, $A_{1}$ : ship tonnage, $A_{2}$ : ship draft, $A_{3}$ : ship type, $A_{4}$ : ship age, $A_{5}$ : bridge location, $A_{6}$ : ship trim.

The same analogy is performed for the algorithm of ship handling facility condition, navigation condition and weather condition.

The next formulation is the formulation of membership function of fuzzy consequence as described in algorithm:

$$
\mu_{f c}(t)=\min (\mu S(t), \mu F(t), \mu N(t), \mu W(t))
$$

where,

$\mu S(t)$ : membership function of the criterion of Ship Condition;

$\mu F(t)$ : membership function of the criterion of Ship Handling Facility Condition;

$\mu N(t)$ : membership function of the criterion of Navigation Condition;

$\mu W(t)$ : membership function of the criterion of Weather Condition.

Further, the formulation membership function of fuzzy solution could be written as illustrated in algorithm:

$$
\mu_{f s}(t)=\max \left(\mu_{f s}(t), \mu_{f c}(t)\right)
$$

where,

$\mu_{f s}(t)$ : membership functions of the fuzzy solution of $x$ until rule of $t$;

$\mu_{f c}(t)$ : membership functions of the fuzzy consequence of $x$ until rule of $t$,

and the final formulation of the implication of fuzzy solution could be written as :

$$
S H D_{s}=\frac{\int_{t} t \mu_{f s}(t) \mathrm{d} t}{\int_{t} \mu_{f s}(t) \mathrm{d} t}
$$

where, $S H D_{s}$ is value of Ship Handling Difficulty.

\section{Simulation}

The simulation of model to assess ship handling difficulty level on several ferry routes in Indonesia is conducted. The first ferry route is Ketapang-Gilimanuk at Bali Strait where is located between East part of Java Island and West part of Bali Island. The second ferry route is Lombok Strait where is located between East part of Bali Island and West Part of Lombok Island.

The simulation of model uses scenario which is developed from several data such ship particular, weather condition and preference state of ship master on ship handling behavior. The ship particular was extracted from website. $[15,16]$. Some ship particular data are created due to limitation of data source. The weather condition was taken from Badan Meteorology Klimatologi Geofisika Indonesia for the date of 14 April 2012 [17]. The preference state of ship master is used and based on another study $[18,19]$. The detail of simulation data is presented in Table 1.

The application of model will use 12 ships for each strait with seven phases of navigation. The seven phases consists of two phases at departure port, three phases at sea area and two phases at arrival port. Therefore, each strait will have 84 scenarios. The detail is presented in Table 2. 
The result of each application scenario is presented in the table form and column chart form. By using algorithm $1-6$, the ship handling value is calculated and processed through two steps which are AHP and FIS. The result of calculation is shown at Table $\mathbf{3}$ as an example.

The calculation result shows that ship handling value for Padangbai (PAD) at Lombok Strait has the highest value both on Minimum SHDs and Maximum SHDs. It means that ship handling difficulty at Padangbai as departure port relatively more difficult than at port of Ketapang (KET), port of Gilimanuk (GIL) and port of Lembar (LEM). Port of Ketapang (KET) has the lowest value of ship handling difficulty.

Meanwhile, at sea area, ferry route of Ketapang-Gilimanuk has higher value of ship handling difficulty than

Table 1. Simulation scenario.

\begin{tabular}{|c|c|c|c|c|c|c|c|}
\hline Ship Condition & Data & Bali & Lombok & Nav. Cond. & Data & Bali & Lombok \\
\hline Tonnage & Real & & & Ship speed & Scenario & 1 & 1 \\
\hline Ship draft & Scenario & 4 & 4 & Depth of water & Scenario & 2 & 2 \\
\hline Ship type & Scenario & 1 & 1 & Communication & Scenario & 2 & 2 \\
\hline Age of ship & Real & 0 & 0 & Ship Position & Scenario & 7 & 7 \\
\hline Bridge position & Scenario & 1 & 1 & Nav.Status & Scenario & 1 & 1 \\
\hline Trim & Scenario & 1 & 1 & Traffic situation & Scenario & 6 & 6 \\
\hline Ship Hand. Fac. Cond & Data & Bali & Lombok & Weather Cond. & Data & Bali & Lombok \\
\hline Main Eng Type & Scenario & 1 & 1 & Wave & Real & 2 & 3 \\
\hline Number ship prop. & Scenario & $1 / 2$ & $1 / 2$ & Wind & Real & 5 & 5 \\
\hline Type prop. & Scenario & 1 & 1 & Current & Scenario & 2 & 2 \\
\hline Number ship rudder & Scenario & $1 / 2$ & $1 / 2$ & Visibility & Scenario & 3 & 3 \\
\hline type ship rudder & Scenario & 1 & 1 & Swell & Real & 2 & 2 \\
\hline Side thruster & Scenario & $1 / 2$ & $1 / 2$ & Day/Night & Scenario & 1 & 1 \\
\hline
\end{tabular}

Table 2. Scenario application of ship handling model.

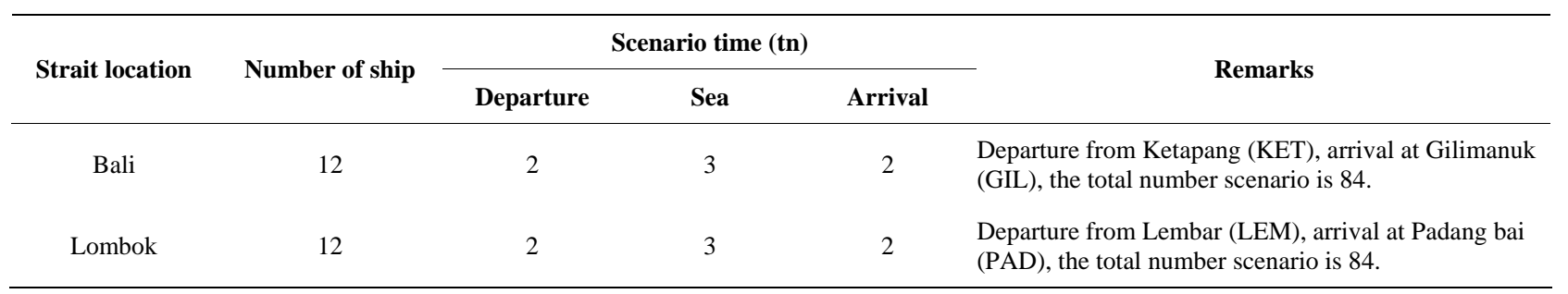

Table 3. Part of ship handling calculation.

\begin{tabular}{|c|c|c|c|c|c|c|c|c|c|c|c|c|}
\hline IF & \multicolumn{2}{|c|}{ Scenario } & \multirow{2}{*}{$\begin{array}{c}\text { A } \\
0.394\end{array}$} & \multirow{2}{*}{$\begin{array}{c}\text { B } \\
0.440\end{array}$} & \multirow{2}{*}{$\begin{array}{c}\text { C } \\
0.145\end{array}$} & \multirow{2}{*}{$\begin{array}{c}\text { D } \\
0.551\end{array}$} & \multirow{2}{*}{$\begin{array}{l}\text { SHDs } \\
1.53\end{array}$} & \multirow{2}{*}{$\begin{array}{l}\text { THEN } \\
\text { THEN }\end{array}$} & \multirow{2}{*}{$\begin{array}{c}\mathbf{X} \\
1.82\end{array}$} & \multirow{2}{*}{$\begin{array}{c}\text { LInguistic } \\
\text { Somewhat Safe }\end{array}$} & \multirow{2}{*}{$\begin{array}{c}\text { Shiphandling Diff. } \\
\text { Negligence }\end{array}$} & \multirow{2}{*}{$\begin{array}{c}\begin{array}{c}\text { Accept. } \\
\text { Criteria }\end{array} \\
\text { Acceptable }\end{array}$} \\
\hline IF & $\mathrm{F} 1$ & $\mathrm{t} 1$ & & & & & & & & & & \\
\hline IF & $\mathrm{F} 1$ & $\mathrm{t} 2$ & 0.394 & 0.440 & 0.145 & 0.551 & 1.53 & THEN & 1.82 & Somewhat Safe & Negligence & Acceptable \\
\hline IF & $\mathrm{F} 1$ & $\mathrm{t} 3$ & 0.394 & 0.425 & 0.147 & 0.522 & 1.49 & THEN & 1.65 & Fairly Safe & Negligence & Acceptable \\
\hline IF & $\mathrm{F} 1$ & $\mathrm{t} 5$ & 0.394 & 0.425 & 0.147 & 0.522 & 1.49 & THEN & 1.65 & Fairly Safe & Negligence & Acceptable \\
\hline IF & $\mathrm{F} 1$ & t6 & 0.394 & 0.436 & 0.145 & 0.568 & 1.54 & THEN & 1.90 & Somewhat Safe & Negligence & Acceptable \\
\hline IF & $\mathrm{F} 1$ & t7 & 0.394 & 0.436 & 0.145 & 0.568 & 1.54 & THEN & 1.90 & Somewhat Safe & Negligence & Acceptable \\
\hline
\end{tabular}




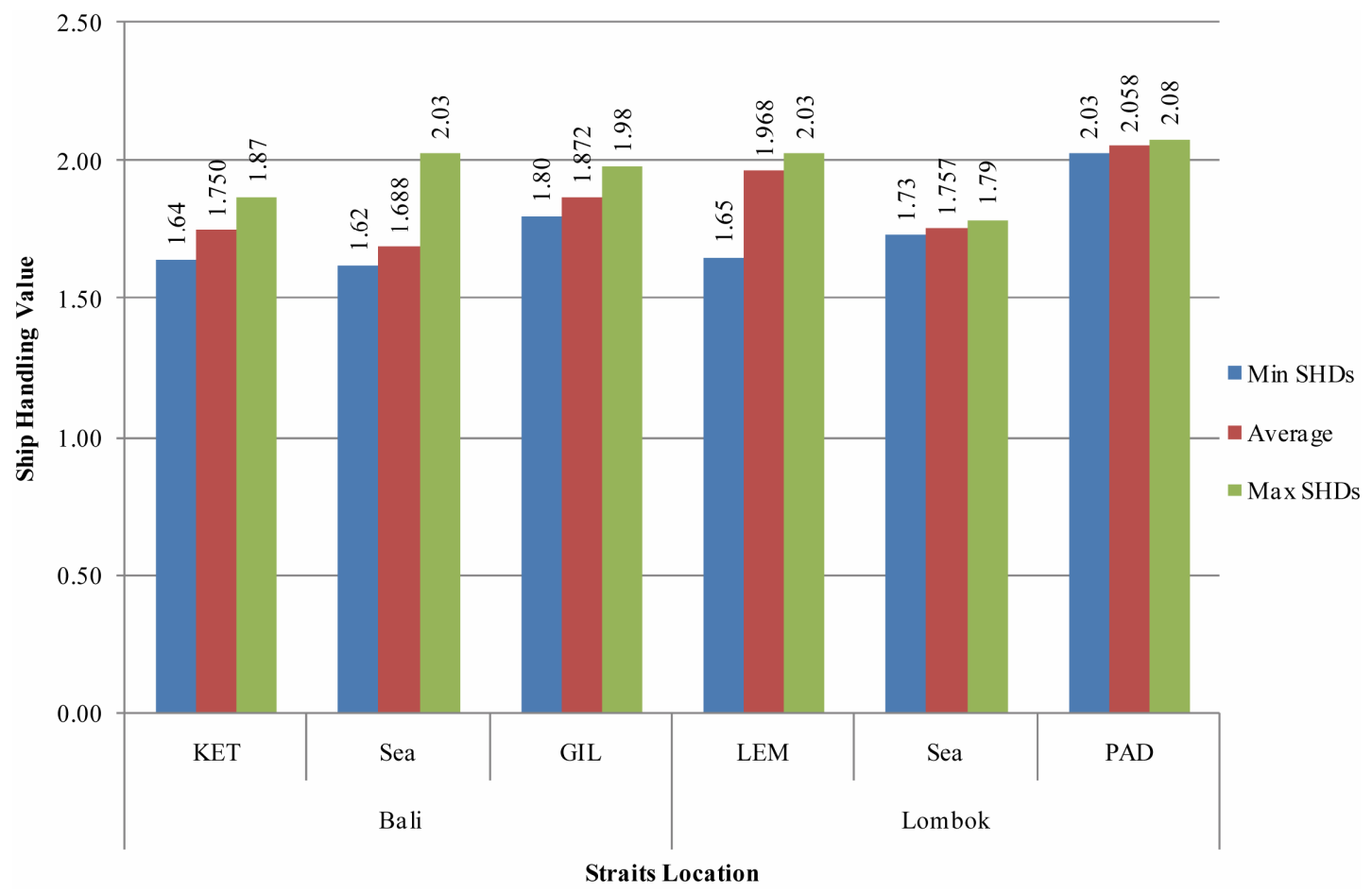

Figure 5. Result of simulation.

ferry route of Padangbai-Lembar. In general, ship handling difficulty at sea area has lower value than at port area. The detail of ship handling value for the simulation is illustrated in Figure 5.

\section{Conclusion}

Based on this approach, port of Padangbai (PAD) has highest ship handling difficulty value in any case followed by port of Lembar (LEM), port Gilimanuk (GIL) and port of Ketapang (KET). Therefore, for ship master at port of Padangbai (PAD) should give attention to ship handling of their ferry. Further, Bali Strait has higher ship handling difficulty on maximum value of SHDs than Lombok Strait. Whereas, in any cases, average value of SHDs showed that Lombok Strait has higher ship handling difficulty than Bali Strait. The result of simulation of ship handling model could be used for several parties concerned such as ship master, shipping company and port authority. Ship master of Ro-Ro ferries should more aware during ship handling process especially during departure and arrival at port. The appropriateness of the arrangement of officer for departure and arrival process would prevent the potential accident refers to ship handling difficulty. Further, the shipping company could establish strategies which are different for each ferry route. Special attention should be given to ferry routes which ship handling difficulty value is in higher level. Finally, the port authority could develop ship handling difficulty index for each ferry route, so each ferry will be justified and verified for ship handling characteristic before they put in to service.

\section{REFERENCES}

[1] Directorate General of Land Transportation, "Land Transportation in Number 2010,” Directorate General of Land Transportation, Ministry of Transportation Indonesia, 2011.

[2] Directorate Coast Guard, "Ship Accident Recapitulation 2003-2009,” Directorate Coast Guard, 2009.

[3] K. Inoue, "Evaluation Method of Ship-handling Difficulty for Navigation Restricted and Congested Waterways,” Kobe University of Merchantile Marine, Kobe, 1998.

[4] A. Priadi, T. Tjahjono and A. Benabdelhafid, "Ship Hand ling Difficulty Decision Tool for Safety Improvement of Ship Operated at Port Water and Strait Water Based on the Combination of AHP and Fuzzy Logic: Study Case Ferry," World Conference Transport Research Society (WCTRS) Conference, Antwerp, 21-22 May 2012.

[5] T. L. Saaty and L. G. Vargas, "Model Methods Concepts and Application of the Analytic Hierarchy Process," Kluwer Academic Publication, Norwell, 2001.

[6] H. Persada, "Study on Determining Hazard Navigation Map through Danger Score by Using AIS Data,” Thesis Paper, Sepuluh Nopember of Institute Technology, Surabaya, 2011.

[7] C. Chuo, "AHP Model for the Container Port Choice in the Multiple-Ports Region,” Journal of Marine Science and Technology, Vol. 18, No. 2, 2010, pp. 221-232.

[8] H. Nguyen, "The Application of the Ahp Method in Ship 
System Risk Estimation,” Polish Maritime Research, Vol. 59, No. 16, 2009, pp. 78-82.

[9] L. Zadeh, "Fuzzy Sets,” Information and Control, Vol. 8, No. 3, 1965, pp. 338-353.

doi:10.1016/S0019-9958(65)90241-X

[10] P. Zalewski, "Risk Assessment of LNG Carrier Systems Failure Using Fuzzy Logic,” Scientific Journal of Maritime University of Szczecin, Vol. 97, No. 2, 2011, pp. 7785.

[11] J. Li, "Risk Assessment Model of High Speed Craft Navigation Based on Fuzzy Analystical Hierarchy Process," Journal of Computational Information System, Vol. 6, No. 5, 2009, pp. 1661-1667.

[12] J. Balmat, F. Lafont, R. Maifret and N. Pessel, "Maritime Risk Assessment (MARISA), a Fuzzy Approach to Define an Individual Ship Risk Factors,” Ocean Engineering, Vol. 36, No. 15, 2009, pp. 1278-1286. doi:10.1016/j.oceaneng.2009.07.003

[13] H. S. Sii, T. Ruxton and J. Wang, “A Fuzzy-Logic-Based Approach to Qualitative Safety Modelling for Marine Systems,” Reliability engineering and System Safety, Vol. 73, No. 1, 2001, pp. 19-34. doi:10.1016/S0951-8320(01)00023-0

[14] A. Priadi, A. Benabdelhafid and T. Tjahjono, "Determining Ship Handling Difficulty Level for Ferries at Port
Water and Strait Water," International Conference on Management, Social and Humanities (ICMeSH), Kuala Lumpur, 2012.

[15] Directorate General of Land Transportation, "Profile and Performance of Land Transportation of Bali Province," Directorate General of Land Transportation, Ministry of Transportation Indonesia, 2011.

[16] Directorate General of Land Transportation, "Profile and Performance of Land Transportation of Nusa Tenggara Barat Province,” Directorate General of Land Transportation, Ministery of Transportation Indonesia, 2011.

[17] BMKG, "Maritime Weather Prediction Sunda Strait, Bali Strait and Lombok Strait,” 2012.

http://maritim.bmkg.go.id/index.php/main/pra_penyebera ngan_det/2

[18] A. Priadi, "Descriptive Study on Determining Ship Handling Difficulty of Ferry: Case Study Ketapang-Gilimanuk," Part of Dissertation Progress Report No. 2, University of Indonesia and University of Le Havre, Le Havre, 2012.

[19] A. Priadi, "Descriptive Study on Determining Ship Handling Difficulty of Ferry: Case Study Lembar-Padangbai,” Part of Dissertation Progress Report No. 3, University of Indonesia and University of Le Havre, Le Havre, 2012. 